\title{
WOMEN'S PAID WORK IN AN URBAN DEVELOPING ECONOMY. BARCELONA IN 1930*
}

JORDI DOMÈNECH

University of York ${ }^{\mathrm{a}}$

ALEXANDER ELU-TERÁN

European University Institute ${ }^{\mathrm{b}}$

\begin{abstract}
In this paper we explore the determinants of women's work using data from Barcelona in 1930. Although participation rates were much lower in Barcelona than in cities in the UK or the US at roughly the same time, our estimates of the labour supply suggest women in Barcelona did respond to wage incentives. The most distinguishable feature of the household division of labour in Barcelona is the lack of substitution effects among family members, especially among women. The sensitivity of the participation of each individual woman to the participation of other members of the household might indicate that labour markets were highly segmented and anticipates the existence of large differences in household earnings and welfare. We argue that the persistence of labour-intensive methods of production requiring on-the-job training might explain the type of household division of labour that we find in Barcelona.
\end{abstract}

\footnotetext{
* Received 04/16/2008. Accepted 09/23/2008. The authors gratefully acknowledge financial support from the Spanish Ministry of Education and Science under grant SEJ-2006-08188/ECON and the Spanish Ministry of Foreign Affairs and the Spanish Agency for International Cooperation (AECI) (Elu). We also thank the three anonymous referees, the editor, and audiences at the University of York and the Lisbon meeting in quantitative Economic History (November 2007).

a Department of Economics and Related Studies, University of York, YORK YO10 5DD, UK. Email: jd551@york.ac.uk.

b Department of History and Civilization, European University Institute, Via Boccaccio 121, I-50133 Firenze, Italy. Email: alexander.elu@eui.eu.
} 
Keywords: labour supply, female occupations, household economy JEL classification: N34, R20, J21, J82

\section{RESUMEN}

Este artículo explora los determinantes del trabajo de las mujeres en la ciudad de Barcelona en 1930. Aunque las tasas de participación en Barcelona eran muy inferiores a las de algunas ciudades británicas o estadounidenses durante el mismo período de tiempo, nuestras estimaciones de la oferta de trabajo sugieren que las mujeres barcelonesas respondían positivamente a los estímulos salariales. Sin embargo, la característica más sobresaliente de la organización familiar del trabajo en el caso barcelonés es la inexistencia de efectos sustitución entre los miembros de la misma unidad familiar, y especialmente entre las mujeres. El hecho de que la decisión individual de cada mujer de participar estuviera positivamente influenciada por la participación de otras mujeres del mismo hogar apunta a la elevada segmentación de los mercados de trabajo y sugiere, a su vez, la existencia de grandes diferencias en los niveles de ganancias y bienestar de los hogares barceloneses de la época. El artículo argumenta que la persistencia de métodos de producción intensivos en trabajo y la acumulación de capital humano en el lugar de trabajo exclusivamente son factores explicativos del patrón de división del trabajo observado en los datos.

Palabras clave: oferta de trabajo, organización del trabajo, ocupación femenina, estructura familiar

\section{INTRODUCTION}

With some lag with respect to other Western European countries, the participation of Spanish women in the labour market has increased fast since the late 1960s. In 1973, the participation rate of women older than 15 and younger than 64 was 35 per cent, while in 2004 it was 57 per cent, lagging 4.5 percentage points behind the average in the Euro area and only higher than Italy and Greece in the same area ${ }^{1}$. The implications of this historical process are far reaching. For example, it has been argued that the historical lag in female participation in the labour force altered the institutional paths of Southern European welfare states, generally precluding the full development of universal social policies ${ }^{2}$.

\footnotetext{
1 Bover (1997, p. 1), Eurostat.

2 Esping-Andersen (1998, p. 83).
} 
In this paper, we collect new data to explore the historical roots of the above-mentioned lag in female labour market participation by looking at the role of women in the labour market and the household in an urban setting in 1930s Spain. We construct a sample of 1,000 households in Barcelona using the 1930 local census (Padrón Municipal) and analyse the determinants of female participation. We think Barcelona is an ideal setting to study the labour market possibilities of household members. It was the most dynamic city of pre-Civil War Spain and attracted a large pool of migrants from other regions ${ }^{3}$. Between 1900 and 1930 the city almost doubled in size (from 544,137 to $1,005,565$ inhabitants) and grew by 40 per cent in the 1920s (population censuses, 1900,1920,1930). Our study expands on previous research on the pre-WW2 household division of labour in Western Europe by providing evidence of a very dynamic labour market.

Historians of women's work in Spain have made important contributions to documenting the extent of women's involvement in late $19^{\text {th }}$ and early $20^{\text {th }}$ century labour markets. Because the population censuses clearly underestimate female participation, historians have relied on detailed local or regional case studies, generally from those areas in which there were opportunities for women to participate in manufacturing work. Examples of this excellent literature include the study by Luisa Muñoz (2006) of the canning industries in Galicia, of Lina Gálvez (1998) for the women employed in the tobacco factory in Seville, the study on the Catalan textile town of Sabadell by Enriqueta Camps $(1997,1998,2004)$ or the work of Pilar Pérez-Fuentes (1993) and Mercedes Arbaiza (1998) on working class households in late $19^{\text {th }}$ and early $20^{\text {th }}$ century Biscay. A general message from this literature is the existence of a vibrant urban labour market for women and especially for married women before the advent of the male breadwinner family later in the $20^{\text {th }}$ century. All these authors explicitly adopted a household context to understand the individual decision of women to participate, especially in the case of married women. Gálvez and Muñoz, for example, emphasised the existence of seasonal work or flexible hours for married women. Camps, on the other hand, concentrated on the substitution of women for children in the context of the fertility transition and the expansion of primary education, suggesting the existence of a more modern pattern of the division of labour in Spanish urban households. Compared to the mid $19^{\text {th }}$ century, the Catalan labour market used fewer young girls and increased the employment of married women ${ }^{4}$. Therefore, the conclusions in this literature are that either Spanish households were at the first end of a U-shaped labor supply curve or that the female participation rates were on the rise (the second part of the U-shaped labor supply). Our results, however, show that when we take a diversified labor market less dominated

\footnotetext{
3 Silvestre (2007, p. 547).

4 Camps (1997, 1998, 2004).
} 
by female-intensive industries, participation rates were probably at the bottom end of the U-shaped labour supply curve ${ }^{5}$.

The international literature has also adopted a household perspective but, in general, we see a more explicit modelling approach to women's individual decision to participate. For example, in their classic study of women's participation in Britain during the industrial revolution, Sarah Horrell and Jane Humphries contended that «perhaps surprisingly, the conventional neoclassical model appears to fit well the behaviour of our early industrial wives and mothers» ${ }^{6}$. They also concluded that women responded positively to wage incentives and negatively to the husbands' wage and that there was a substitution between mothers and their daughters once the latter could work, so that mothers had a higher participation rate when their children were very young. In her study of late $19^{\text {th }}$ century Philadelphia, Claudia Goldin stressed that the participation of young women depended positively on the absence of mothers and the presence of younger siblings ${ }^{7}$. Elyce Rotella emphasised that the participation of mothers was very sensitive to household characteristics, and that of young women less so over time $^{8}$. Using data from the 1920 US population census, Marco Manacorda found that children becoming eligible for work did not change the labour supply of both parents ${ }^{9}$. Timothy Hatton and Roy Bailey's work on households in interwar London and York argued that marriage, rather than children, reduced participation and that part of the increase in household chores generated by more children fell on other females in the household ${ }^{10}$. Historically, comparatively low wage and high income elasticities in both the UK and the US before WW2 explain why participation rates were low and even falling before WW2 ${ }^{11}$.

This paper is divided as follows. Section II presents the data and establishes comparisons with other examples from Spain, the UK and the US. Section III presents estimates of the labour supply for working class households in Barcelona, focussing especially on the wage and income elasticities of families. Section IV discusses interactions in the households pinning down the main hypotheses of substitution of mothers for children and substitution-effects among women in the household.

\footnotetext{
5 On the U-shaped labor supply curve, see Mammen and Paxson (2000); Goldin (1995).

6 Horrell and Humphries (1995, p. 111).

7 Goldin (1979, p. 127).

8 Rotella (1980, p. 112).

9 Manacorda (2006, p. 1788).

10 Hatton and Bailey (1993, p. 248).

11 Goldin (1990, pp. 133-36); Hatton and Bailey (1993, p. 249).
} 


\section{DATA AND COMPARISONS}

This paper uses a hitherto relatively unexplored source of demographic and occupational information, the 1930 Padrón Municipal of Barcelona ${ }^{12}$. In spite of coinciding with a census year in the case of Barcelona, most commonly the padrones appeared in the mid 1920s in an effort of the Primo de Rivera dictatorship to collect data on living standards in urban areas. In the case of Barcelona, it was probably the sheer volume of the task that delayed its implementation until 1929. The Barcelona padrón fills 800 books of roughly 300 pages each, each page giving information on one household from a total of about 256,000 households. As a first approximation, we have collected less than 1 per cent of this information, generating a sample of 1,000 household cards, of which 971 had usable information (offices or shops were also included in the cards). The cards were given by a municipal agent and, in theory, filled in and signed by each household head (although whether household heads filled in the cards themselves or whether it was the agent is not easy to ascertain). In the case of illiterate household heads, the municipal agent signed the card. Each card gives information regarding the number of people living in each household unit, their age, their family relationship, the presence of boarders, whether household members were literate or illiterate, their occupation or whether they stayed at home, went to school, or were unemployed or unable to work (due to illness, accident or old-age), whether the dwelling was owner-occupied or rented, where were they born and for those born outside Barcelona, the number of years since arrival in the city.

We collected our data by choosing 10 census books at random in each of the 10 Barcelona districts and selecting 10 pages at random in each book (there was one household per page). Our sample contains 1,599 women and girls older than 13. This was the minimum age to be eligible to work legally at the time and we found almost no cases of girls younger than 13 working. The literature agrees that minimum age restrictions were enforced in urban areas, although very young workers were found by studies of rural areas in the same period ${ }^{13}$. Of the 1,599 women, 361 report an occupation and therefore the participation rate is roughly 23 per cent. When we re-weigh by the sample probability, the overall participation rate is 25 per cent. It is always difficult to define exactly what it meant to be working in this period and whether the local census captured part-time or occasional market work. However, it is clear that the way the local census was organised and its emphasis on the living standards of urban households, it is a more reliable source than the population census. We can therefore measure women's paid work outside and inside the home with a sufficient degree of accuracy.

12 Important exceptions are Oyón, Maldonado, Griful (2001), Oyón (2008).

13 Camps (1998); Borrás Llop (1995). On the presence in rural areas, Reher (1990). 
We begin by analysing the occupational structure of the city. By far the most common occupation is that of housemaid, representing 44 per cent of all participating women. 30 per cent of participants recorded jobs in industry. Additionally, 2 per cent were apprentices, probably in factories, 10 per cent were seamstresses, 4 per cent were employed in shops and 2 per cent had office jobs. 3 per cent held miscellaneous jobs ranging from teacher to cabaret artist. One problem which affects male occupations especially but also affects female occupations, is the large proportion of unspecified industry jobs - the category «jornalero», literally meaning working for a daily wage. We believe this category had a clear meaning at the time, probably reflecting a large pool of workers with a non-structured set of skills. We checked the 1925 figures for the industrial town of Sabadell (roughly 40,000 inhabitants in 1920), which, at first sight, provide far better information regarding the occupation and earnings assigned to each member of the household. This information was more detailed especially regarding jobs in the textile industry (predominant in the town), but we still find a lot of male and female jornaleros. Furthermore, the wages of these jornaleros were very homogenous (between 7 and 8 ptas. a day for men in Sabadell in 1925). Although we believe that the occupational information in our data set could be improved, the large share of jornaleros partly reflects the existence of a large pool of floating workers, who had accumulated experience but did not enter an internal labour market of promotions within the firm. Although there are few studies of labour mobility in late $19^{\text {th }}$ and early $20^{\text {th }}$ century in Western European and North-American firms, the literature has stressed the existence of high levels of mobility in preWorld War 1 labour markets ${ }^{14}$.

Compared to the padrón of Sabadell, participation rates in Barcelona were slightly higher at younger ages and lower for married women. The participation rate of women in the age group 20-24 was 39 per cent in Barcelona and about 25 per cent in Sabadell (31 per cent in Barcelona if we exclude housemaids) ${ }^{15}$. Married women in Sabadell maintained participation rates between 15 to 20 per cent from their early 20s to their mid 40s, whereas in Barcelona the corresponding figure was below 10 per cent. Only in the case of women older than 45 did Barcelona have some (small) advantage, but this advantage only existed when housemaids were included in the Barcelona sample. Participation rates in Sabadell were below 10 per cent for women older than 45, while in Barcelona they were between 10 and 15 per cent. In general, the existence of promotion ladders and internal labour markets for women, noted in Sabadell for the 1920s by Enriqueta Camps,

${ }^{14}$ Carter and Savoca (1990); Jacoby (1992); for the German case, Brown and Neumeier (2001, p. 214); Domènech (2008), forthcoming, for female floating workers in the Catalan textile industry.

${ }^{15}$ Average calculated by re-weighting by the sample probability. 
seems to be very specific to this textile town ${ }^{16}$. Tables 1 and 2 show the participation rates by age and marital status in Barcelona.

Participation rates in Barcelona in 1930 can also be compared with cities in more developed economies. The proportion of married women working in Barcelona was 6.7 per cent (table 2) ${ }^{17}$, which can be compared with data from the 1911 Census of England and Wales from Hatton and Bailey (2001, p. 95): Northampton, 11.5 per cent, Warrington, 6.5 per cent, Reading, 5.4 per cent, Bolton, 15 per cent. For working class households in London and York, the participation rates of wives were 6 per cent and 4.3 per cent respectively ${ }^{18}$. We can also compare the Barcelona rates with data from 3 cities in the NorthEast of the US in 1920: in Baltimore the participation rate of married women was 14 per cent, it was 6 per cent in Pittsburgh, and 25 per cent in Fall River ${ }^{19}$. As in Spain, textile towns in the US (Fall River) and the UK (Bolton) had more generous labour market opportunities for women after marriage.

Table 3 compares participation rates for women classified by age in Barcelona with rates in London in 1929. London, at that time, had an unemployment rate of 8.5 per cent ${ }^{20}$, our evidence from the local padrón is that Barcelona was nowhere near this level of unemployment. High unemployment rates in London and lower ones in Barcelona mean that we have a low bound of the differences in female participation between the two labour markets (we would expect higher female participation rates with lower unem-

TABLE 1

SAMPLE PARTICIPATION RATES OF BARCELONA WORKING CLASS WOMEN, 1930 ACCORDING TO THEIR MARITAL STATE. 90 PER CENT CONFIDENCE BANDS IN BRACKETS

\begin{tabular}{|l|c|c|}
\hline & Total & Participation \\
\hline Single & 462 & $\begin{array}{c}0.49 \\
{[0.457-0.534]}\end{array}$ \\
\hline Married & 539 & $\begin{array}{c}0.08 \\
{[0.06-0.1]}\end{array}$ \\
\hline Widows & 212 & $\begin{array}{c}0.19 \\
{[0.148-0.238]}\end{array}$ \\
\hline All & 1211 & $\begin{array}{c}0.26 \\
{[0.238-0.279]}\end{array}$ \\
\hline
\end{tabular}

Source: Own elaboration from Barcelona 1930 local census.

16 Camps (1997, 1998, 2004).

17 The unweighted average is 8.5 . Calculated by re-weighting by the sample probability.

18 Hatton and Bailey (1993, p. 239).

19 Kleinberg (2005, p. 66).

20 Hatton and Bailey (1993, p. 234). 


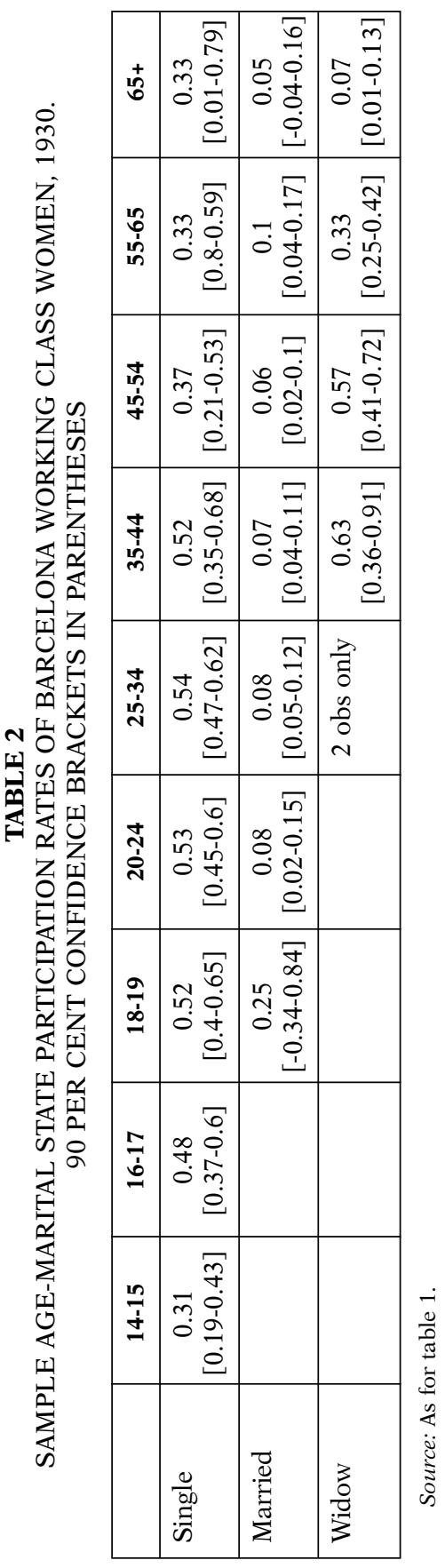


TABLE 3

SAMPLE PARTICIPATION RATES OF WORKING CLASS WOMEN, IN PERCENTAGES. BARCELONA AND LONDON AROUND 1930. (90 PER CENT CONFIDENCE INTERVALS FOR BARCELONA IN BRACKETS)

\begin{tabular}{|c|c|c|c|}
\hline $\begin{array}{c}\text { Age } \\
\text { intervals }\end{array}$ & $\begin{array}{c}\text { Barcelona, } 1930 \text { local } \\
\text { census, working class } \\
\text { women only. Percentages }\end{array}$ & $\begin{array}{l}\text { Barcelona } 1930 \text { working } \\
\text { class women excluding } \\
\text { housemaids. Percentages }\end{array}$ & $\begin{array}{l}\text { London, 1929-31 } \\
\text { NSLLL. } \\
\text { Percentages }\end{array}$ \\
\hline $14-15$ & $\begin{array}{c}31 \\
{[19-43]}\end{array}$ & $\begin{array}{c}24 \\
{[12-35]}\end{array}$ & 62 \\
\hline $16-17$ & $\begin{array}{c}58 \\
{[48-67]}\end{array}$ & $\begin{array}{c}43 \\
{[32-54]}\end{array}$ & 90 \\
\hline $18-19$ & $\begin{array}{c}50 \\
{[38-62]}\end{array}$ & $\begin{array}{c}34 \\
{[21-47]}\end{array}$ & 93 \\
\hline $20-24$ & $\begin{array}{c}41 \\
{[35-47]}\end{array}$ & $\begin{array}{c}23 \\
{[17-29]}\end{array}$ & 74 \\
\hline $25-34$ & $\begin{array}{c}28 \\
{[24-33]}\end{array}$ & $\begin{array}{c}16 \\
{[12-20]}\end{array}$ & 29 \\
\hline $35-44$ & $\begin{array}{c}18 \\
{[14-23]}\end{array}$ & $\begin{array}{c}14 \\
{[9-17]}\end{array}$ & 19 \\
\hline $45-54$ & $\begin{array}{c}16 \\
{[11-19]}\end{array}$ & $\begin{array}{c}8 \\
{[5-12]}\end{array}$ & 19 \\
\hline $55-59$ & $\begin{array}{c}17 \\
{[9-24]}\end{array}$ & $\begin{array}{c}13 \\
{[6-20]}\end{array}$ & 19 \\
\hline $60-64$ & $\begin{array}{c}13 \\
{[7-19]}\end{array}$ & $\begin{array}{c}9 \\
{[3-16]}\end{array}$ & 16 \\
\hline $65-69$ & $\begin{array}{c}8 \\
{[1.4-14]}\end{array}$ & $\begin{array}{c}6 \\
{[0.3-12]}\end{array}$ & 15 \\
\hline $70+$ & $\begin{array}{c}11 \\
{[3.2-19]}\end{array}$ & $\begin{array}{c}5 \\
{[0-11]}\end{array}$ & 6 \\
\hline
\end{tabular}

Sources: 1930 Barcelona local census. Hatton and Bailey (2001) for London 1929-1931 (original data in the New Survey of London Life and Labour). Working class households in Barcelona selected by occupation of the household head.

ployment in London). As in London, participation rates initially increased with age and then fell quite abruptly after the age of 20 . However, London had almost universal participation among working class teenagers while the rate was much lower in Barcelona (about half of the London rate if we include housemaids and slightly more than a third if we exclude them to make the samples more comparable). Participation stabilised after the age of 35 at a low level and then started falling after 60 years of age. Compared with London, women younger than 35 worked less in Barcelona, but between this 
age and their mid 60s, women in both cities showed a similar tendency to participate (albeit at a slightly lower rate in Barcelona). Working opportunities for older women (65 and above) were limited in Barcelona, whereas in London working class women showed relatively high rates of participation until the age of 69 . The participation rates of women older than 70 were lower in Barcelona, but the rates are calculated on very small sample sizes.

Table 3 shows the distinctive features of the Barcelona household model. Participation rates of married women are slightly lower but still comparable to other historical experiences. Enriqueta Camps has shown that female participation rates of married women had been increasing since the mid $19^{\text {th }}$ century, while the rate for children had been falling ${ }^{21}$. Table 3 also shows that the most distinctive feature of the Barcelona model is the lower levels of participation in Barcelona of young, probably still single, women compared with cities in more developed economies. We analyse the labour market behaviour of young women with the aim of under standing why working class teenangers and their families behaved so differently in Barcelona in comparison with other historical experiences.

\section{ESTIMATING THE LABOR SUPPLY OF WORKING CLASS HOUSEHOLDS IN BARCELONA}

We model the decision to participate in the labor market using the standard tools of neoclassical economics, following the literature on the topic ${ }^{22}$. The decision to participate depends on the weighting of the potential wage that the woman can obtain in the labor market with the value of household work and leisure (both determining her reservation wage). We obtain a reduced form equation in which the decision to participate is a function of the potential wage, the household income, and the demand for household work proxied by the characteristics of the family. As we do not have estimates of hours worked for women in paid labor, our labor supply model only considers the decision to participate.

We attempt to set our variables and samples in such a way as to make the analysis comparable with published studies, most notably that of Hatton and Bailey (1993). For this reason, only working class households are used in our dataset. This decision is taken, firstly, to make the regressions comparable with Hatton and Bailey's use of interwar social surveys of working class households in several cities in Britain. Secondly, because it was easier to assign earnings to the occupations of women (for this purpose we used the data published by the Spanish Ministry of Labor of the wages broken down by a wide range of occupations and gender in 1930,

21 Camps (1995); Rosés (1998, p. 130).

22 Goldin (1979); Hatton and Bailey (1993); Horrell and Humphries (1995). 
complementing this when necessary with the 1925 Sabadell census). Regressions are performed for two different samples, one including all working class women, another excluding housemaids. In our view, since housemaids and servants tended to lodge with their middle or upper-class employers, they were most probably not recorded in the social surveys.

As stated in the previous section, housemaids represented 44 per cent of the employed women in Barcelona and were by far the most common female professional group. This group of workers had several distinctive features. Compared with other active working class women, housemaids were not younger (the average age for housemaids was 30 years old, while for active working class women it was 31 ). However, only 12 per cent had been born in the province of Barcelona (as opposed to 48 per cent of the active women) and their average length of stay had been about 7.5 years (as opposed to 18 years for active, immigrant women) ${ }^{23}$. Since it is impossible to collect the household characteristics of these workers, we have excluded them from the working class sample.

Moving to the statistical analysis. Firstly, we deal with the problem of selection bias by generating predicted wages for all women in the sample using the available information we have on working women (137 cases). We regress the $\log$ of the wage against a series of individual characteristics which, on a priori grounds, reflect human capital (including age, age squared, literacy, and whether the person was born in Barcelona) and dummies for the district in which the household lived. We correct for sample selection bias by entering a lambda variable from a first stage probit model ${ }^{24}$. This variable takes into account the unmeasured characteristics of those who work which might enhance their earnings. The predicted values for each woman are generated from:

[1] $E_{i}=\alpha+\beta X_{i}+$ error 1 ,

[2] $\log w_{i}=\gamma+\delta Z_{i}+\varepsilon \cdot \lambda_{i}+$ error 2 ,

where $E_{i}$ is a dichotomous variable taking value 0 if person $i$ does not work and 1 if $i$ works, $X_{i}$ is a vector of personal and household characteristics, and $Z_{i}$ is a vector of alternative personal and household characteristics. Here, we consider that almost none of $X_{i}$ variables is in $Z_{i}$ but in fact it is difficult to think of personal or household characteristics that might affect wages and not participation or participation and not wages. However, several of the personal and household characteristics are strongly correlated (for example age and

${ }^{23}$ Standard deviations for years since «registration in Barcelona» were 8 for immigrant housemaids and 14 for other active women.

${ }^{24}$ "Lambda» is the inverse Mill's ratio which is equal to the ratio between the value of the standard normal density function that corresponds to the fitted value of the participation equation divided by the value of the normal cumulative function that corresponds to that same fitted value. See Heckman (1980). 
marital status or number of children). For this reason and also because we have a relatively small sample size, we consider the wage is exclusively affected by orthodox human capital variables like years of professional experience (proxied by age) or human capital (proxied by literacy). In addition, we also make the fairly large assumption that only the potential wage, the age, and the household characteristics have an impact on participation. We also exclude age in the participating equation in one of the specifications, making these quite large assumptions to make our results as comparable as possible with previous studies like those of Hatton and Bailey (1993) and Horrell and Humphries (1995), which do not include age as a regressor in the participating equation. Since different areas in Barcelona seemed to have been highly specialised in particular sectors (for example manufacturing in areas like Sants or Sant Martí), we also include dummies for the district (distrito, the administrative division of Barcelona into 10 broad areas) to capture local employment opportunities, although they are always statistically insignificant. Finally, $\lambda_{i}$ captures correlated unobserved characteristics of those participating.

Table 4 reports the coefficients of the earnings equation:

TABLE 4

WAGE REGRESSIONS

\begin{tabular}{|l|c|}
\hline \multirow{2}{*}{ Age } & Salaried women excluding servants \\
\cline { 2 - 2 } & Coefficient \\
\hline Age squared & $0.041^{* * *}$ \\
& $(0.012)$ \\
\hline Literate=1 & $-0.005^{* * *}$ \\
& $(0.0015)$ \\
\hline Born in Barcelona $=1$ & 0.097 \\
& $(0.1)$ \\
\hline Constant & 0.027 \\
& $(0.078)$ \\
\hline Lambda & 0.94 \\
& $(0.25)$ \\
\hline District dummies & -0.12 \\
\hline Adj-R squared & $(0.09)$ \\
\hline Chi-Squared & Yes \\
\hline N & 0.35 \\
\hline
\end{tabular}

Notes: Standard errors in parentheses. ${ }^{* *}$ means statistically significant at the 1 per cent level, $* *$ at the 5 per cent level. 
Results from table 4 show that women's wages rose slowly, peaked before the age of 40 and fell quickly after that age. The non-reported coefficients for some of the city districts were always non-significant. The coefficient of the lambda variable is positive, as expected, but not significant. The overall explanatory power of the regression is rather low, only 11 per cent. The predicted wages are introduced into our participating equation, where the probability of working depends on the predicted wage from the wage equation corrected for selection, whether the woman was the household head or whether she was married to the household head, the relative number of children between 0 and 6 years old (scaled down by the number of non-dependents, non-dependents being defined by the number of household members older than 12), and the number of people reported to work (scaled by the number of non-dependents). Unfortunately, we cannot gather information on aggregate income in the family. In addition, it is not very useful to impute wages to male workers because of the large proportion of jornaleros included in our data. Since we only consider working class households, we can proxy aggregate household income (except the income of the participating women) using the relative number of additional participants (scaled by the number of non-dependents) and also controlling for whether the household was headed by a woman. We tried controlling for the fact that among working class households the household head was reported to be a jornalero or some other factory or workshop occupation. However, no significant difference was detected when using this variable. We also controlled for proxies of wealth like home ownership, but found that there was too little variation in the variable (paying rent was the almost universal option for working class households in the period). The specification is:

$$
\text { [3] } E_{i}=\alpha+\zeta \cdot \hat{w}_{i}+\eta \cdot Z_{i}+\text { error, }
$$

where $E_{i}$ is a dichotomous variable taking value 1 if $i$ works and 0 if $i$ does not work, $\hat{w}_{i}$ is the predicted wage and $Z_{i}$ is the vector of personal and household characteristics (age, marital status, number of children in relation to the number of non-dependents, the household labour supply except $i$ scaled by the number of of non-dependents). Table 5 reports the marginal effects from a probit regression on all women, married women only, widows, and singles including age as a regressor and table 6 includes specifications excluding age which allow for comparisons with Bailey and Hatton (1993) and Horrell and Humphries (1995):

In the case of the sample containing all women, we have reasonable explanatory power and in all the specifications the main determinants of the participation decision are marriage and the proportion of other members in the household eligible for work the members of household eligible for work (13 or older). Marriage reduced the probability of working with respect to the base group (non-household head widows and singles with no family) by more than 50 per cent. Being the household head, on the other 
TABLE 5

INDIVIDUAL PARTICIPATION ESTIMATES. WORKING CLASS HOUSEHOLDS

\begin{tabular}{|c|c|c|c|c|}
\hline & $\begin{array}{c}\text { All women } \\
\text { Mean } \\
\text { participation=0.11 }\end{array}$ & $\begin{array}{c}\text { Married } \\
\text { Mean } \\
\text { participation }=0.06\end{array}$ & $\begin{array}{c}\text { Widows } \\
\text { Mean } \\
\text { participation }=0.15\end{array}$ & $\begin{array}{c}\text { Singles } \\
\text { Mean } \\
\text { participation }=0.29\end{array}$ \\
\hline & $\mathrm{dF} / \mathrm{dx}$ & $\mathrm{dF} / \mathrm{dx}$ & $d F / d x$ & $\mathrm{dF} / \mathrm{dx}$ \\
\hline $\begin{array}{l}\text { Female } \\
\text { household } \\
\text { head }\end{array}$ & $\begin{array}{c}0.047 \\
(0.039)\end{array}$ & $\begin{array}{l}0.161^{*} \\
(0.124)\end{array}$ & $\begin{array}{l}0.007 \\
(0.05)\end{array}$ & $\begin{array}{c}0.182 \\
(0.143)\end{array}$ \\
\hline Wife of head & $\begin{array}{c}-0.18 * * * \\
(0.025)\end{array}$ & & & \\
\hline Log (age) & $\begin{array}{c}-0.104 * * * \\
(0.025)\end{array}$ & $\begin{array}{l}-0.038 \\
(0.031)\end{array}$ & $\begin{array}{c}-0.46^{* * * *} \\
(0.101)\end{array}$ & $\begin{array}{l}-0.022 \\
(0.078) \\
\end{array}$ \\
\hline $\begin{array}{l}\text { Other } \\
\text { working/non } \\
\text { dependents }\end{array}$ & $\begin{array}{l}0.32 * * * \\
(0.048)\end{array}$ & $\begin{array}{l}0.149 * * * \\
(0.056)\end{array}$ & $\begin{array}{c}0.209 \\
(0.092)\end{array}$ & $\begin{array}{l}0.9 * * * \\
(0.132)\end{array}$ \\
\hline $\begin{array}{l}\text { Children } \\
\text { 0-6/non } \\
\text { dependents }\end{array}$ & $\begin{array}{c}0.037 \\
(0.026)\end{array}$ & $\begin{array}{l}-0.006 \\
(0.024)\end{array}$ & $\begin{array}{c}0.016 \\
(0.062)\end{array}$ & $\begin{array}{c}0.114 \\
(0.083)\end{array}$ \\
\hline $\begin{array}{l}\text { Log (predicted } \\
\text { wage) }\end{array}$ & $\begin{array}{l}0.051 * \\
(0.029)\end{array}$ & $\begin{array}{l}-0.029 \\
(0.033)\end{array}$ & $\begin{array}{c}0.03 \\
(0.054) \\
\end{array}$ & $\begin{array}{l}0.22 * * * * \\
(0.089)\end{array}$ \\
\hline Log-likelihood & -361 & -118 & -61 & -158 \\
\hline Pseudo- $^{2}$ & 0.17 & 0.04 & 0.22 & 0.18 \\
\hline $\mathrm{X}^{2}$ & 149 & 9.26 & 34.9 & 71.1 \\
\hline $\mathrm{N}$ & 1006 & 518 & 188 & 320 \\
\hline
\end{tabular}

Note: Standard errors in parentheses. $* * *$ means statistically significant at the 1 per cent level, ${ }^{* *}$ at the 5 per cent level, * at the 10 per cent level.

hand, did not have an impact on the probability of participating, except in the case of married women. We can only speculate, but this situation might include absent husbands or husbands who migrated. We find a large, positive effect of the relative household supply. The existence of a positive effect of other members of the household working is suggestive of positive income effects within this sub-sample of Barcelona households, although this variable probably also captures unobserved household characteristics which increase the probability of participation ${ }^{25}$.

In table 5, the estimate of the wage elasticity for the sample of all women is 0.05 and is statistically significant. Since predicted wages are predicted

25 A similar effect was found in the case of young girls in Britain during the Industrial Revolution by Horrell and Humphries (1995, p. 507). 
TABLE 6

INDIVIDUAL PARTICIPATION ESTIMATES. WORKING CLASS HOUSEHOLDS

\begin{tabular}{|c|c|c|c|c|}
\hline & $\begin{array}{c}\text { All women } \\
\text { Mean } \\
\text { participation }=0.11\end{array}$ & $\begin{array}{c}\text { Married } \\
\text { Mean } \\
\text { participation }=0.06\end{array}$ & $\begin{array}{c}\text { Widows } \\
\text { Mean } \\
\text { participation }=0.15\end{array}$ & $\begin{array}{c}\text { Singles } \\
\text { Mean } \\
\text { participation }=0.29\end{array}$ \\
\hline & $\mathrm{dF} / \mathrm{dx}$ & $\mathrm{dF} / \mathrm{dx}$ & $d F / d x$ & $\mathrm{dF} / \mathrm{d} x$ \\
\hline $\begin{array}{l}\text { Female } \\
\text { household } \\
\text { head }\end{array}$ & $\begin{array}{l}-0.02 \\
(0.03)\end{array}$ & $\begin{array}{c}0.135 \\
(0.115)\end{array}$ & $\begin{array}{l}-0.025 \\
(0.049)\end{array}$ & $\begin{array}{c}0.174 \\
(0.133)\end{array}$ \\
\hline Wife of head & $\begin{array}{c}-0.23 * * * * \\
(0.02)\end{array}$ & & & \\
\hline $\begin{array}{l}\text { Other } \\
\text { working/non } \\
\text { dependents }\end{array}$ & $\begin{array}{c}0.32 * * * * \\
(0.05)\end{array}$ & $\begin{array}{l}0.144^{* * *} \\
(0.056)\end{array}$ & $\begin{array}{l}0.115 \\
(0.09)\end{array}$ & $\begin{array}{l}0.948 \\
(0.13)\end{array}$ \\
\hline $\begin{array}{l}\text { Children } \\
0-6 / \text { non } \\
\text { dependents }\end{array}$ & $\begin{array}{l}0.008 \\
(0.46)\end{array}$ & $\begin{array}{r}-0.002 \\
(0.03)\end{array}$ & $\begin{array}{c}0.05 \\
(0.112)\end{array}$ & $\begin{array}{c}0.06 \\
(0.164)\end{array}$ \\
\hline $\begin{array}{l}\text { Log (predicted } \\
\text { wage) }\end{array}$ & $\begin{array}{c}0.18^{* * * *} \\
(0.05)\end{array}$ & $\begin{array}{l}-0.043 \\
(0.06)\end{array}$ & $\begin{array}{c}0.325^{* * * *} \\
(0.076)\end{array}$ & $\begin{array}{l}0.368 * * \\
(0.152)\end{array}$ \\
\hline Log-likelihood & -365.85 & -118.85 & -68.77 & -159 \\
\hline Pseudo-R ${ }^{2}$ & 0.17 & 0.03 & 0.13 & 0.18 \\
\hline $\mathrm{X}^{2}$ & 139.51 & 7.87 & 20.7 & 69.5 \\
\hline $\mathrm{N}$ & 1006 & 518 & 188 & 320 \\
\hline
\end{tabular}

Note: Standard errors in parentheses. $* * *$ means statistically significant at the 1 per cent level, $* *$ at the 5 per cent level, * at the 10 per cent level.

mostly using age, we have excluded age from the regressions in table 6, which, as mentioned above, are similar to Hatton and Bailey (1993) and Horrell and Humphries (1995). Our estimate of the wage elasticity of the labor supply, excluding age as a regressor, is highly significant and comparable to existing estimates, although the variation in the literature is huge. Using interwar social surveys for London and York, Hatton and Bailey obtained an elasticity for all women of $0.2^{26}$. For the US before the Great Depression, Frauendord and Rotella found elasticities which were very close to $0^{27}$. Sarah Horrell and Jane Humphries, on the other hand, found an elasticity larger than 1.5 for married women during the Industrial Revolution ${ }^{28}$. With the latter exception, the elasticities found in the histori-

\footnotetext{
26 Hatton and Bailey (1993, pp. 242-243).

27 Quoted in Goldin (1990, p. 132), Costa (2000, p. 115).

28 Horrell and Humphries (1997, p. 114).
} 
cal literature are well below present-day elasticities and the case of Barcelona seems to be an example of a case with small, but strictly positive elasticities.

In the case of married women, widows and singles, the results are also consistent with prior expectations. Married women have a zero elasticity (table 6), which is not surprising given their general low level of participation and the very mild increase in participation in their 50s (in spite of the fact that wages increased with age). Widows and single women had more elastic labor supplies, a result which was also found by Hatton and Bailey in interwar London and York ${ }^{29}$. In the case of girls, participation increased fast with age in their teens along with predicted wages, explaining the result. Additionally, the effect of the proportion of other household members working is very strong and highly significant for single women. For married women it is about a fifth of the effect on singles, while for widows it is not different from 0 .

Proxying for the constraints imposed by household work, the number of dependents in all cases (in this framework defined as children between 0 and 6 years as a proportion of members of the household older than 13) did not affect the participation decision. We have checked for other proxies for childcare duties — children younger than 1 or dependents younger than 13- and, although the coefficient is negative for married women and positive for singles, we do not find any statistically significant effect of children on the participation decision for any of the groups. Especially in the case of married women, Barcelona women seem to be quite different from their counterparts in the US and the $\mathrm{UK}^{30}$, where the participation decision was more sensitive to the household composition, especially when children were present.

Finally, in our working class sub-sample, there is some evidence of positive income effects (with income proxied by the relative household labour supply), which seems to run contrary to current wisdom on the historical female labor supply. From the literature, we would expect wage elasticities to be low and positive and income effects to be large and negative. The Barcelona result is paradoxical. The coefficient on the proportion of household members working probably masks unobserved characteristics that predict that the household has high or low levels of participation. These unobserved characteristics might be access to labor market information or some privileged position in the labor market guaranteeing that entry into the market was easier for household members.

For exploratory purposes, we regressed the share of working members on total non-dependent household members against household size, the relative number of dependents to non-dependents, a dummy variable cap-

29 Hatton and Bailey (1993, p. 243).

30 Rotella (1980, p. 112), Hatton and Bailey (1993, pp. 242-243). 
turing whether the head of the household was born in the province of Barcelona and the number of years since arrival into Barcelona (in the case of local household heads - born in the province of Barcelona- we set the years equal to their age until 1930), and dummies for the district in which the families lived. The regressions show that larger households benefited from economies of scale, i.e. their relative labour supply scaled by the number of non-dependents was higher. Being born in Barcelona, living in an industrial district of the city (Sants, Sant Andreu or Sant Martí) is associated with higher relative participation (with statistically significant coefficients at standard levels). Furthermore, recent arrivals had lower relative household participation. Including all of these variables (being born in the province of Barcelona, years living in Barcelona, or the city-district dummies) in the participation equation does not alter the main results and most of the included variables were not statistically significant at standard levels ${ }^{31}$.

There is clear variation in female employment rates at the district level, with the industrial districts of Sant Martí or Sants having participation rates of about 20 per cent and as low as 5 per cent in Eixample (when we exclude housemaids). If local employment opportunities matter, this might have increased or decreased the probability of participation for all females in a given household. Indeed, the best historical study we have on commuting and distances to work for Barcelona shows workers in some important factories in Barcelona lived next to or very close to the factory. 40 per cent of workers at the Maquinista y Terrestre in Sant Andreu in the 1930s lived in a radius of 600 metres from the factory. At the Barceloneta factory of the same company, 68 per cent of workers lived in a radius of 2 kilometres and 38 per cent in a radius of 600 metres $^{32}$. Similarly, 80 per cent workers in the large textile factory Rivière, in Poble Nou, employing slightly more than 1,000 workers of which a third (33.8 per cent) were women, lived in a radius of less than 2 kilometres. 38 per cent lived within 600 metres of the factory ${ }^{33}$. Some relationship exists, therefore, between the variation in participation rates by district and the concentration of industrial firms in some areas of the city. Clearly, living in districts with large industrial firms might have increased the probability of participation of all members of the household. It is unclear, however, whether particularly industrious households moved into areas with good employment opportunities or whether firms relied on the relatively immobile local pool of labor.

It is clear, therefore, that our alleged positive income effect could be simply capturing unmeasured household characteristics or variations in local employment opportunities. Having said that, our data do not contra-

\footnotetext{
31 Regressions available upon request from the authors.

32 Oyón (2008, pp. 245-246).

33 Oyón (2008, p. 252).
} 
dict the general message in the literature: the potential positive income effect disappears if we extend the sample to include other social groups. Table 7 shows the participation rates of single women according to the profession of the household head using all our sample of households. Daughters of liberal professionals (lawyers, doctors, etc.) have zero participation rates, those of shopkeepers and clerical workers have higher participation rates and the highest participation rates are found among households headed by salaried workers. The difference of means between participation in the salaried worker group and the rest is significant at the 1 per cent level. We should control for many other household and individual characteristics, but the magnitude of the effect suggests that, if we could control properly for household income, we would get a large, negative coefficient for the whole sample. However, this fact does not invalidate the result that better-off working class families had higher participation rates and that there is no substitution among members of the household. Working class households in Barcelona were, in this case, quite different than working class households in the UK.

\section{INTERACTIONS AMONG HOUSEHOLD MEMBERS}

Interactions among household members are explored to understand the factors explaining the relatively low level of participation of girls in our sample and the comparatively high level of participation of married women (quite high compared with contemporary examples, very low if measured against current levels of participation). We start with the analysis of married women. The main hypothesis to explain the participation of urban wives in Catalan towns was put forward by Enriqueta Camps ${ }^{34}$ who stated that in a context of the transition to a low fertility regime and hig-

\section{TABLE 7}

PARTICIPATION OF SINGLE WOMEN,

BY PROFESSION OF THE HOUSEHOULD HEAD (EXCLUDES HOUSEMAIDS)

\begin{tabular}{|c|c|}
\hline Head professional group & Participation of single women \\
\hline Professional & 0 \\
Clerical & 0.18 \\
Shop & 0.15 \\
Salaried worker & 0.34 \\
& F-test for differences in means $=10.61 \% * *$ \\
\hline
\end{tabular}

Note: ***Statistically significant at the 1 per cent level. F-test against null-hypothesis that the mean particpation in the salaried group is the same as the mean participation in the other groups.

${ }^{34}$ Most forcefully in Camps (1998). 
her investments in children's education, coupled with legal restrictions on the employment of children, mothers increasingly substituted for children ${ }^{35}$. In this setting, the most industrialised area of Spain would have household structures comparable to other developed areas in Western Europe and the fertility transition would be linked to higher participation rates of women.

Given its inherently dynamic narrative, this hypothesis is difficult to test with our cross-sectional data. As a first result, we do not see the number of children affecting the labor supply of mothers, suggesting that higher participation and lower fertility might not be directly related, i.e. if fertility rates were falling around 1930, women had fewer children and families invested more in education before the increase in the participation rates of married women. A second way of looking at the hypothesis is to check what happened when children became eligible to work. Did this have any significant impact on the labor supply of mothers? This hypothesis would mean that the participation of married women, controlling for household characteristics and the rising wage profile, should have been higher in households in which children were younger than 14. It also means that, controlling for household characteristics and the potential wage, as children turned 14, the participation of married women should, ceteris paribus, have declined.

The regression in table 8 compares the participation of married women and widows with children of school age with married women and widows whose children are eligible to work or who do not yet have children. The regression confirms the message of the previous regressions; it was marriage, not children that put women outside the labor market. The fact that children were of school age did not alter the labor supply of mothers relative to childless wives or mothers whose children were eligible to work. Instead of declining as their children became able to contribute to the household economy, married women's participation rates increased slightly as they became older, peaking after the age of 55 (table 2). Our Barcelona example shows there was very little substitution taking place between mothers and children and that children's eligibility to work did not alter the labor supply behavior of mothers.

We have mentioned how the labor supply behavior of girls is the most distinctive feature of the household division of labor in Barcelona. Labor supply regressions show clearly how young women responded to wage incentives. However, participation rates for young women in working class households in Barcelona were low in comparative terms. One reason might be that there was more substitution taking place between brothers and sisters or between young women and other earners (including mothers) in Barcelona households than elsewhere. In our previous regression, the positive elasticity of the participation decision relative to the proportion of eli-

35 Camps (1998, p. 149). 
TABLE 8

INDIVIDUAL PARTICIPATION ESTIMATES. MARRIED WOMEN AND WIDOWS (WORKING CLASS SAMPLE EXCLUDING HOUSEMAIDS)

\begin{tabular}{|l|c|c|}
\hline & $\begin{array}{c}\text { Widows and married } \\
\text { women }\end{array}$ & Married only \\
\cline { 2 - 3 } & $\mathbf{d F / d x}$ & $\mathbf{d F / d x}$ \\
\hline Household head & $\begin{array}{c}0.113^{* * *} \\
(0.04)\end{array}$ & $0.1 *$ \\
\hline Other working / non & $0.114^{* *}$ & $(0.05)$ \\
dependents & $(0.047)$ & -0.004 \\
\hline Children 7-13 & 0.013 & $(0.015)$ \\
\hline Children 0-6 & $(0.14)$ & 0.003 \\
\hline Ln (predicted wage) & -0.007 & $(0.014)$ \\
\hline Log likelihood & $(0.02)$ & -0.033 \\
\hline Pseudo R & 0.02 & $(0.034)$ \\
\hline Chi ${ }^{2}$ & $(0.03)$ & -124 \\
\hline $\mathrm{N}$ & -200 & 0.02 \\
\hline
\end{tabular}

Note: Standard errors in parentheses. ${ }^{* * *}$ means statistically significant at the 1 per cent level, ${ }^{* *}$ at the 5 per cent level, * at the 10 per cent level.

gible household members working was positive, showing that very limited substitution was taking place between members of the household. We explored this variable further to analyse the response of young women to the participation of other household members. Two probit regressions in which the decision to participate depends on the existence of other household members (we abstract for this time from wages and other considerations) were performed. We use one specification with the absolute number of other household earners and another with proportions. The exercise controls for the presence of a working father or a working mother, the number of children in the 0-6 age bracket and the number of children and teenagers going to school. We also controlled for household size to see whether the number of members in a household alters the decision making process ${ }^{36}$. To capture the interactions between the secondary household earners ${ }^{37}$ several variables were used: the absolute number of secondary workers, the pro-

\footnotetext{
36 Lanjouw and Ravallion (1995).

37 We define secondary workers as workers other than the household head (employed or not).
} 
portion of secondary earners among household members minus any of the surviving parents in the household, the absolute number of male secondary workers, the proportion of male secondary workers in the household except any surviving mother or father, the proportion of female secondary workers in the household except any surviving mother and father, the proportion of male secondary workers among male household members except the male household head (if alive), the proportion of female secondary workers among female household members except the wife of the household head or any female household head. We also included dummies for age intervals $(14-15,16-17,18-19)$ and for the distrito, which, however, were not significant and are not reported here.

Results in table 9 put the Barcelona case in clear contrast with late $19^{\text {th }}$ and early $20^{\text {th }}$ century UK and US experiences. In Barcelona, young women were very sensitive to the household composition, contrary to the experiences of urban women in North-American and British cities in which single women had very high participation rates and their participation did not depend on household characteristics ${ }^{38}$. The regressions in table 9 are generally well behaved and with respectable explanatory power. The regressions improve substantially when we decompose the effect of other secondary earners on the individual probability of participating in a male and female effect. The evidence indicates very little substitution between mothers and daughters - on the contrary, the participation of mothers increases the probability of daughters working - and a 0 elasticity of the labor supply of young women to the absence of the main income earner. Other secondary earners have a strong positive impact on the probability of working, but this effect happens especially, or even exclusively, among women and girls. The work of brothers or other secondary male earners did not have any effect on the probability of working. However, the market participation of mothers and other sisters or female kin clearly increases the probability of working for young women, with an extra female secondary worker in the household increasing the baseline probability by 0.55 (for a girl in a working class household with no female secondary earners and the mean number of male secondary earners who are eligible to work, an extra female secondary earner triples the probability of participating) ${ }^{39}$. The result of this effect is that households with a greater number of women show higher participation rates (table 10), strongly suggesting that very little substitution is taking place.

We have explored in the previous section the very plausible possibility that the absence of substitution between household members could be related to unmeasured household characteristics (to a certain extent reinforced by variations in local employment opportunities). A complementary expla-

\footnotetext{
38 Hatton and Bailey (1993, p. 249); Rotella (1980, p. 112).

39 Using the regression with absolute numbers.
} 
TABLE 9

PARTICIPATION OF TEENAGERS OLDER THAN 13 (14 TO 19) AND HOUSEHOLD COMPOSITION. MEAN PARTICIPATION IS 0.37

\begin{tabular}{|c|c|c|c|c|c|}
\hline & Absolute & $\begin{array}{c}\text { Proportions } \\
\text { (per cent) }\end{array}$ & Absolute & $\begin{array}{l}\text { Proportions } \\
\text { (per cent) }\end{array}$ & $\begin{array}{c}\text { Proportions } \\
\text { (per cent) }\end{array}$ \\
\hline & $\mathrm{dF} / \mathrm{dx}$ & $\mathrm{dF} / \mathrm{dx}$ & $\mathrm{dF} / \mathrm{d} \mathbf{x}$ & $\mathrm{dF} / \mathrm{dx}$ & $\mathrm{dF} / \mathrm{dx}$ \\
\hline $\begin{array}{l}\text { Male head } \\
\text { earner }\end{array}$ & $\begin{array}{c}0.002 \\
(0.134)\end{array}$ & $\begin{array}{c}-0.045 \\
(0.14)\end{array}$ & $\begin{array}{c}-0.074 \\
(0.153)\end{array}$ & $\begin{array}{c}-0.081 \\
(0.16)\end{array}$ & $\begin{array}{c}-0.1 \\
(0.16)\end{array}$ \\
\hline Mother earner & $\begin{array}{l}0.34 * * \\
(0.15)\end{array}$ & $\begin{array}{l}0.303^{*} \\
(0.16)\end{array}$ & $\begin{array}{c}0.24 \\
(0.17)\end{array}$ & $\begin{array}{c}0.21 \\
(0.19)\end{array}$ & $\begin{array}{c}0.21 \\
(0.19)\end{array}$ \\
\hline Other earners & $\begin{array}{c}0.16^{* * * *} \\
(0.06)\end{array}$ & $\begin{array}{c}0.007 * * * * \\
(0.21)\end{array}$ & & & \\
\hline $\begin{array}{l}\text { Male other } \\
\text { earners except } \\
\text { male household } \\
\text { head }\end{array}$ & & & $\begin{array}{l}0.027 \\
(0.07)\end{array}$ & $\begin{array}{c}0.0021 \\
(0.0025)\end{array}$ & $\begin{array}{c}-0.0005 \\
(0.002)\end{array}$ \\
\hline $\begin{array}{l}\text { Female other } \\
\text { earners except } \\
\text { female household } \\
\text { head }\end{array}$ & & & $\begin{array}{c}0.55 * * * \\
(0.11)\end{array}$ & $\begin{array}{c}0.022 * * * \\
(0.005)\end{array}$ & $\begin{array}{c}0.017 * * * \\
(0.003)\end{array}$ \\
\hline $\begin{array}{l}\text { Children in } \\
\text { school/eligible } \\
\text { to work }\end{array}$ & $\begin{array}{c}-0.02 \\
(0.054)\end{array}$ & $\begin{array}{c}0.0002 \\
(0.0023)\end{array}$ & $\begin{array}{c}0.06 \\
(0.06)\end{array}$ & $\begin{array}{c}0.00167 \\
(0.00243)\end{array}$ & $\begin{array}{c}0.001 \\
(0.0024)\end{array}$ \\
\hline $\begin{array}{l}\text { Children } 0-6 / \\
\text { eligible to work }\end{array}$ & $\begin{array}{l}0.15^{*} \\
(0.08)\end{array}$ & $\begin{array}{c}0.004 \\
(0.0024)\end{array}$ & $\begin{array}{l}0.19 \div * * \\
(0.09)\end{array}$ & $\begin{array}{c}0.0042 \\
(0.0025)\end{array}$ & $\begin{array}{c}0.0041 \\
(0.0026)\end{array}$ \\
\hline Household size & $\begin{array}{l}-0.05 \\
(0.043)\end{array}$ & & $\begin{array}{l}-0.07 \\
(0.05)\end{array}$ & $\begin{array}{l}-0.018 \\
(0.031)\end{array}$ & $\begin{array}{l}-0.015 \\
(0.033)\end{array}$ \\
\hline Log likelihood & -72 & -71 & -58 & -58 & -57 \\
\hline Pseudo R Sq & 0.1 & 0.12 & 0.27 & 0.28 & 0.28 \\
\hline Chi Sq & 15.8 & 18.4 & 43.4 & 44.4 & 45.4 \\
\hline $\mathrm{N}$ & 122 & 122 & 122 & 122 & 122 \\
\hline
\end{tabular}

Note: Standard errors in parentheses. *** means statistically significant at the 1 per cent level, ** at the 5 per cent level, * at the 10 per cent level.

nation for the positive correlation of the female labor supply with respect to the participating mother and sisters or other women in the same household unit could be the fact that most of the jobs available for women in Barcelona in the 1930s were in the manufacturing sector. Using the population census for the province of Barcelona, we see that 65 per cent of workers were women in the textile sector, 62 per cent in the garment industry, 
TABLE 10

NUMBER OF WOMEN PER HOUSEHOLD AND PARTICIPATION RATES

\begin{tabular}{|c|c|}
\hline $\begin{array}{c}\text { Number of women-girls older } \\
\text { than 13 per household }\end{array}$ & Participation rate \\
\hline 1 & 0.085 \\
2 & 0.141 \\
3 & 0.208 \\
4 & 0.238 \\
5 & 0.364 \\
\hline
\end{tabular}

Note: There were some examples of households having more than 5 women, but sample size in each category is too small to draw conclusions.

but only 0.5 per cent in the metal industries or 0.25 per cent in the building industry ${ }^{40}$. Industries like food or printing had employment shares for women of around 15 to 20 per cent. There are several pieces of evidence showing that the employment of women was restricted in collective contracts in the early 20th century. The collective contract of «cilindradores $y$ aprestadores» (two textile occupations) contained explicit restrictions regarding the jobs women could do (art. 10) and suppressed the employment of girls (art. 11) ${ }^{41}$. Similarly, in the printing trades (especially among binders) the union lobbied mainly to forbid the employment of women ${ }^{42}$. In contrast, 97 per cent of unionised workers in the textile industry in 1905 were women ${ }^{43}$.

Skills in the textiles or garment sectors were acquired on the job and via an unstructured process of training. Because workers differed markedly in terms of training and their quality was difficult to observe, manufacturing establishments - especially in the textile sector- recruited teams of related workers rather than individual workers ${ }^{44}$. Only later in the century, with the expansion of service jobs and the increase in the supply of general human capital, could firms hire individual workers with a recognisable set of skills. The expansion of jobs for young workers and women which took off in interwar Britain - requiring few skills or a very well defined set of general skills supplied by specialised institutions - might have eased this transition from a "collective» or "team» labor supply to a more individual labor supply ${ }^{45}$. Studying this transition will require matching demographic household data with far more detailed occupational data -including the firms

${ }^{40}$ Population Census of 1930, Dirección General (1932).

${ }^{41}$ Sastre (1904, p. 19).

${ }^{42}$ Sastre (1905, p. 5).

43 Sastre (1907, p. 13).

${ }_{44}$ Domenech (2007, p. 17); Camps (1990, p. 313); Camps (1995, pp. 181-216); Camps (1998, p. 141).

${ }^{45}$ Heim (1984, p. 591). 
in which household members are working- but, in our opinion, this transition did not take place in Spain until the 1960s. Suffice to say here that the existence of other women working in the household greatly increases the probability of participating for other women in the household. This effect however did not depend on the family being of recent arrival in Barcelona. Both native and immigrant women seemed to have faced the same constraints. The benefits for insiders in the labor market were obviously considerable and suggest that the main constraints for labor market participation for women were not on the supply side but on the side of demand, with highly segmented labor markets and restrictions to entry for women.

\section{CONCLUSIONS}

This paper studies the participation of women and girls in interwar Spain using a detailed data set from Barcelona in 1930. In comparative terms, we find that the participation rates of women in Barcelona were substantially lower than rates in cities in more developed economies. This result masks the relatively low participation rates of young women and relatively high participation rates of women older than 25 (comparing Barcelona with cities in the UK and the US). Women in Barcelona did, however, respond to wage incentives: our estimates of the labor supply provide wage elasticities which are lower than the current elasticities, but are, however, comparable with the elasticities in the US and the UK. Although we are not able to approximate the income effect accurately, our results seem to indicate less negative income effects. One of our main results is that a higher relative presence of other income earners had a strong effect on the probability of working for all women in the household.

Relatively high participation rates of married women are not explained by having fewer children or providing them with an education. As in London or York in the 1930s, marriage, not children, significantly reduced participation rates for wives. Participation rates simply increased with age (participation rates of wives in their mid fifties were higher than for younger wives). This increase did not track, however, the rising age-earnings profile. Moreover, there is no evidence of substitution between children eligible to work and mothers.

Girls and young women clearly identify the Spanish model, which has far lower participation rates for young women compared to the UK, for example, in the same period. The labor supply of young women differed from the labor supply of the same group in the US and the UK in that it was very sensitive to the household composition and especially the presence of other earners. By far the most significant characteristic is that the probability of working for any individual young woman or girl depends positively on sisters or other female secondary earners (also on mothers, but to a far 
lesser extent). Our explanation for this phenomenon is probably technological, reflected in a slow rate of structural change. In the absence of institutions providing vocational training and with most skills being acquired on the job, firms relied on working teams to guarantee the quality of their working force. This hypothesis cannot be tested, however, with the available data and more definitive conclusions on the role of technological paradigms will have to await future research.

\section{PRIMARY SOURCES}

Padrón de habitantes de Barcelona (1930), Arxiu Administratiu de l'Ajuntament de Barcelona (Administrative Archive of the Council of Barcelona).

Padrón de habitatantes de Sabadell (1925-1926), Arxiu Municipal de Sabadell (Municipal Archive of Sabadell).

\section{REFERENCES}

Arbaiza Vilallonga, M. (1998): «Labor migration during the first phase of Basque industrialization: The labor market and family motivations». The History of the Family. An International Quarterly, 3(2), pp. 199-219.

BoRRÁs LLOP, J. M. (1995): «Actitudes patronales ante la regulación del trabajo infantil, en el tránsito del siglo XIX al Xx. Salarios de subsistencia y economías domésticas». Hispania, LV/2, 190, pp. 629-644.

BOVER, O. (1997): «Cambios en la composición del empleo y actividad laboral femenina». Banco de España-Servicio de Estudios, wp 9714.

Brown, J. C., and Neumeier, G. (2001): «Job tenure and labour market dynamics during high industrialisation: the case of Germany before World War I». European Review of Economic History, 5, 2, pp. 189-219.

CAMPS, E. (1990): «La teoría del capital humano: una contrastación empírica. La España Industrial en el siglo XIX». Revista de Historia Económica, VIII, pp. 305-333.

- (1995): La formación del mercado de trabajo industrial en la Cataluña del siglo XIX. Madrid: Ministerio de Trabajo y Seguridad Social.

- (1997): «Las transformaciones del mercado de trabajo catalán, 1850-1925: migraciones, ciclos de vida y economías familiares». Revista de Historia Industrial, 11, pp. 45-72.

- (1998): «Transitions in women's and children's work patterns and implications fort he study of family income and household structure: A case study from the Catalan textile sector (1850-1925)». The History of the Family. An International Quarterly, 3, 2, pp. 137-153.

- (2004): «Wage Structures and Family Economies in the Catalan Textile Industry in an Age of Nascent Capitalism». Continuity and Change, 19, 2, pp. 265-281.

CARTER, S., and SAVOCA, E. (1990): «Labor mobility and lengthy jobs in nineteenth-century America». Journal of Economic History, 50, pp. 1-16.

Costa, D. L. (2000): «From mill town to board room: the rise of women's paid labor». Journal of Economic Perspectives, 14, pp. 101-132.

Dirección General del Instituto Geográfico Catastral y Estadístico (1932): Censo de la población de España de 1930. Madrid: Talleres del Instituto Geográfico y Catastral. 
DomÈnEch, J. (2008): «Labour market adjustment a hundred years ago. The case of Catalan textiles, 1880-1913». Economic History Review, 63, 1, pp. 1-27.

EsPing-ANDERsEn, G. (1998): Social foundations of postindustrial economies. Oxford: Oxford University Press.

FRAUENDORD, M. N. (1979): "The labor force participation of turn of the century married women». Journal of Economic History, 39, pp. 401-418.

GÁlveZ MuÑoz, L. (1998): «Breadwinning patterns and family exogenous factors: Workers at the Tobacco Factory of Seville during the industrialization process, 1887-1945». International Review of Social History, supplement 5, pp. 87-128.

GoldiN, C. (1979): «Household and market production of families in a late nineteenth century American city». Explorations in Economic History, 16, pp. 111-131.

- (1990): Understanding the gender gap: an economic history of American women. New York: Oxford University Press.

Hatton, T. J., and BaiLEY, R. E. (1993): «Household labor supply and women's work in interwar Britain». Explorations in Economic History, 30, pp. 229-256.

- (2001): «Women's work in census and survey, 1911-1931». Economic History Review, LIV, pp. 87-107.

Heckman, J. J. (1980): «Sample selection bias as a specification error», in J. P. SMith (ed.): Female labor supply: theory and estimation. New Jersey: Princeton University Press.

Heim, C. H. (1984): «Structural transformation and the demand for new labor in advanced economies: interwar Britain». Journal of Economic History, XLIV, pp. 585-595.

Horrell, S., and Humphries, J. (1995): «Women's labor force participation and the transition to the male-breadwinner family, 1790-1865». Economic History Review, 48 , pp. 89-117.

JACOBY, S. M., and SHARMA, S. (1992): «Employment duration and industrial labor mobility in the United States, 1880-1980». Journal of Economic History, 52, pp. 161180.

KLEINBERG, S. J. (2005): “Children's and mothers' wage labor in three Eastern U.S. cities, 1880-1920». Social Science History Association, 29, 1, pp. 45-76.

Lanjouw, P., and Ravallion, M. (1995): «Poverty and household size». Economic Journal, 104, pp. 1415-1435.

Mammen, K., and Paxson, C. (2000): «Women's work and economic development». Journal of Economic Perspectives, 14, pp. 141-164.

MANACORDA, M. (2006): "Child labor and the labor supply of other household members: evidence from the 1920s». American Economic Review, 96, pp. 1788-1800.

Ministerio de Trabajo y Previsión Social (1931): Estadísticas de salarios y jornadas de trabajo referida al período 1914-1930. Madrid: Imprenta de los Sucesores de M. Minuesa de los Ríos.

MuÑoz ABeledo, L. (2006): «Labour segmentation in the Spanish fish-canning: a historical perspective, 1880-1960». Continuity and Change, 21, 3, pp. 475-501.

Oyón, J. L. (2008): La quiebra de la ciudad popular. Espacio urbano, inmigración y anarquismo en la Barcelona de entreguerras, 1914-1936. Barcelona: Ediciones del Serbal.

Oyón, J. L.; Maldonado, J., and GRIful, E. (2001): Barcelona, 1930. Un atlas social. Barcelona: Edicions UPC.

PÉREZ-Fuentes, P. (1993): Vivir y morir en las minas: estrategias familiares y relaciones de género en la primera industrialización vizcaína (1877-1913). Bilbao: Universidad del País Vasco.

Reher, D. S. (1990): Town and Country in Preindustrial Spain. Cuenca, 1550-1870. Cambridge: Cambridge University Press. 
Rosés, J. R. (1998): «Measuring the Contribution of Human Capital to the development of Catalan Factory System». European Review of Economic History, 2, 1, pp. 25-48.

Rotella, E. (1980): "Women's labor force participation and the decline of the family economy in the United States». Explorations in Economic History, 17, pp. 95-117.

SASTRE, M. (1904): Las huelgas en Barcelona y sus resultados durante el año 1903. Acompañados de numerosos datos estadísticos sobre asuntos relacionados con la cuestión social obrera en Barcelona. Barcelona: Tipografía Ramón Pujol.

- (1905): Las huelgas en Barcelona y sus resultados durante el año 1904. Barcelona: Tip. La Industria de Manuel Tasis.

- (1906): Las huelgas en Barcelona y sus resultados durante el año 1905. Barcelona: Tip. La Hormiga de Oro.

Silvestre, J. (2007): «Temporary internal migrations in Spain, 1860-1930». Social Science History, 31, 4, pp. 539-574. 